\title{
ANALYSIS OF DIVERGENCE BETWEEN THE AXES OF DENTAL IMPLANTS INSTALLED USING A CLASSIC FREEHAND TECHNIQUE
}

Ivaschenko AV, Yablokov AE $\square$, Fedyaev IM, Tlustenko VP, Rotin NE, Tugushev W

Samara State Medical University, Samara, Russia

Accuracy is a common challenge in dental implant placement. A successful clinical outcome is largely determined by accurate positioning of the implant at the prepared site and proper angulation. This study aimed to compare the divergence between the axes of the implants installed using a classic freehand technique. Cartesian coordinates of implant necks were determined on the CT images of 34 patients in the XOY (horizontal) plane, followed by the coordinates of implant apices. The obtained data were submitted to the original software developed by the authors (patent 2018661716) that automatically computed an angle between the insertion axes of the installed implants. We found that in $87 \%$ of cases, this angle was significantly greater (up to $27^{\circ}$ ) than recommended by implantation dentistry guidelines $\left(7^{\circ}\right)$. In $100 \%$ of the studied cases, the implants were not parallel; in sector 1 , the deviation was $27^{\circ} 4$.

Keywords: dental implantation, navigation system, freehand placement

Author contribution: Ivaschenko AV — study design, data acquisition, manuscript draft; Yablokov AE — data acquisition and analysis, manuscript draft; Fedyaev IM — study design, manuscript editing; Tlustenko VP — data analysis, manuscript editing; Rotin NE — study design, data acquisition; Tugushev VV — study design, manuscript editing.

Compliance with ethical standards: this study was conducted in compliance with the ethical standards for specialized medical care (Order $1525 \mathrm{n}$ of the Ministry of Healthcare of the Russian Federation, dated December 2012) and approved by the Ethics Committee of Samara State Medical University (Protocol 673/17 dated September 11, 2018). The patients gave written informed consent to participate.

$\triangle$ Correspondence should be addressed: Alexey E. Yablokov

Chapaevskaya 89, Samara, 443099; s1131149@yandex.ru

Received: 26.10.2018 Accepted: 04.04.2019 Published online: 15.04.2019

DOI: $10.24075 /$ brsmu.2019.027

\section{АНАЛИЗ УГЛОВЫХ ОТКЛОНЕНИЙ МЕЖДУ ОСЯМИ ДЕНТАЛЬНЫХ ИМПЛАНТАТОВ, УСТАНОВЛЕННЫХ ПО КЛАССИЧЕСКОЙ МЕТОДИКЕ}

\author{
А. В. Иващенко, А. Е. Яблоков ${ }^{凶}$, И. М. Федяев, В. П. Тлустенко, Н. Е. Ротин, В. В. Тугушев \\ Самарский государственный медицинский университет, Самара, Россия
}

\begin{abstract}
Наиболее распространенной сложностью при постановке имплантатов является затрудненный выбор пространственного положения имплантатов. При интеграции имплантатов в полость рта две трети успеха операции зависят от того, насколько точно врач выберет позицию и угол наклона имплантата. Одной из важных проблем при установке имплантатов является их позиционирование в костном ложе. Целью работы было провести сравнительный анализ угловых отклонений дентальных имплантатов, установленных по классической методике, по «методу свободной руки» («rеe hand»). Использовали следующий алгоритм исследования. В декартовой системе координат на КТ-снимке в плоскости ХОҮ (горизонтальная плоскость) определяли координать шеек сравниваемых имплантатов у 34 исследуемых пациентов. Затем находили координаты апикальных частей всех исследуемых имплантатов. Полученные координаты помещали в разработанную нами программу ЭВМ № 2018661716 «Программа расчета угловых отклонений дентальных имплантатов", которая автоматически вычисляла угловое отклонение между осями установленных имплантатов. Расчет угловых отклонений между осями дентальных имплантатов у пациентов в послеоперационном периоде показал в 87\% случаев значительное отклонение угла (до $27^{\circ}$ ) между осями имплантатов по сравнению с общепринятыми в дентальной имплантологии пределами (до $7^{\circ}$ ). В $100 \%$ изучаемых случаев не было отмечено параллельной установки дентальных имплантатов; анализ результатов дентальной имплантации в 1-м секторе выявил угловые отклонения в $27^{\circ} 4^{\prime}$
\end{abstract}

Ключевые слова: дентальная имплантация, навигационная платформа, метод свободной руки

Информация о вкладе авторов: А. В. Иващенко - написание статьи, разработка дизайна исследования, подбор клинического материала; А. Е. Яблоков - написание статьи, подбор клинического материала, анализ полученных данных; И. М. Федяев - разработка дизайна исследования, редактирование статьи; В. П. Тлустенко - редактирование, анализ полученных данных; Н. Е. Ротин - разработка дизайна исследования, подбор клинического материала; В. В. Тугушев - разработка дизайна исследования, редактирование.

Соблюдение этических стандартов: исследование проведено в соответствии с этическими стандартами оказания специализированной медицинской помощи (Приказ Министерства здравоохранения России от 24 декабря 2012 г. № 1525н) и одобрено этическим комитетом Самарского государственного медицинского университета (протокол № 673/17 от 11 сентября 2018 г.). Все пациенты подписали информированное согласие на участие в исследовании.

$\triangle$ Для корреспонденции: Алексей Евгеньевич Яблоков

ул. Чапаевская, д. 89, г. Самара, 443099; s1131149@yandex.ru

Статья получена: 26.10.2018 Статья принята к печати: 04.04.2019 Опубликована онлайн: 15.04.2019

DOI: $10.24075 /$ vrgmu.2019.027

Accurate positioning and proper angulation of a dental implant determine successful treatment outcomes and contribute to the durability of an implant prosthesis. In Russia, the freehand approach has become a gold standard in implant dentistry [1]. The decision about implant positioning is guided by a surgeon's professional expertise. A misangled implant poses a serious problem for further treatment. According to the official guidelines, the maximum acceptable divergence between the implants is $7^{\circ}[1]$. A few researchers report that in some cases the freehand technique can result in a substantial divergence of up to $35^{\circ}$ [2].

Angulation can be significantly improved by using surgical navigation systems that guide the placement of a dental implant $[3,4]$. Such systems minimize angular deviation from an implant's axis, bringing it to the acceptable $7^{\circ}$ [5-7]. However, these platforms are not widely applied in clinical routine because they are too costly and can be only used by specially trained surgeons [8-11]. In light of this, freehand surgery still remains 
one of the most popular methods of implant placement that, unfortunately, can negatively affect treatment outcome if performed unskillfully [12-15].

Stability of dental implants can be evaluated by measuring osseointegration of the installed implant using such systems as Periotest or Osstell ISQ [16, 17].

The aim of this study was to compare divergence between the insertion axes of dental implants installed using a classic freehand technique.

\section{METHODS}

The study was carried out at the facilities of the Maxillofacial Surgery Unit of Samara State Medical University between 2015 and 2018. All patients underwent clinical examination. Their medical histories were also taken; complaints, unhealthy habits and comorbidities that could cause postoperative complications or be regarded as contraindications for dental implantation were noted down. The study included 32 partially edentulous patients of both sexes, aged 18 to 65 years, with no comorbidities. The majority of the participants (53.1\%) were females aged 26 to 66 years (Table 1). Dental implantation was performed using a classic freehand technique. Postoperatively, the patients underwent a CT scan (Vatech Pax Duo scanner; Vatech; Korea).

\section{RESULTS}

A follow-up clinical examination was conducted in the postoperative period. The patients' complaints (including those of pain) and body temperature were taken; facial configuration, tissue condition at the site of surgery, implant excursion, sutures and gingiva formers were evaluated.

The MISS and DENTIUM dental implants (Israel) were installed following a conventional two-step protocol. The procedure was carried out by a dental surgeon specialized in implant dentistry. The number and size the installed implants are given in Table 2.

Ten patients were randomly selected for a CT scan (Vitech Pax Duo) in order to estimate the average divergence between the axes of the installed implants. The angles were calculated using the following algorithm (software patent 2018661716):

$\alpha=\arccos \frac{|(\vec{a}, \vec{b})|}{|\vec{a}| \cdot|\vec{b}|}=\arccos \frac{\left|a_{x} \cdot b_{x}+a_{y} \cdot b_{y}+a_{z} \cdot b_{z}\right|}{\sqrt{a_{x}^{2}+a_{y}^{2}+a_{z}^{2}} \cdot \sqrt{b_{x}^{2}+b_{y}^{2}+b_{z}^{2}}}$,

$\vec{a}=\left(a_{x}, a_{y}, a_{z}\right)$ and $\vec{b}=\left(b_{x}, b_{y}, b_{z}\right)$,

$\cos \alpha=\frac{|(\vec{a}, \vec{b})|}{|\vec{a}| \cdot|\vec{b}|}=\frac{\left|a_{x} \cdot b_{x}+a_{y} \cdot b_{y}+a_{z} \cdot b_{z}\right|}{\sqrt{a_{x}^{2}+a_{y}^{2}+a_{z}^{2}} \cdot \sqrt{b_{x}^{2}+b_{y}^{2}+b_{z}^{2}}}$

A total of 22 implants were analyzed in 10 patients.

Briefly, Cartesian coordinates of necks of the compared implants were determined on the CT image in the XOY (horizontal) plane (Fig. 1A) followed by the coordinates of apices (Fig. 1B). The obtained data were fed to the software developed by the authors of this study (patent 2018661716 issued September 12, 2018); the software computed the angle between the axes of the installed implants.

Then, the data were structured and analyzed, and the dynamics of angular deviations were determined.

In $100 \%$ of the studied cases, the implants were not parallel. In sector 4 , the implants were minimally divergent. On average, the angle between the insertion axes ranged from $2^{\circ} 58^{\prime}$ to $5^{\circ} 4^{\prime}$, falling into the accepted range of deviations. In sectors 2 and 3 , the angles between the insertion axes of the installed implants varied from $3^{\circ} 4^{\prime}$ and $17^{\circ} 96^{\prime}$ (sector 3 ) and from $1^{\circ} 83^{\prime}$ to $17^{\circ} 75^{\prime}$ (sector 2 ), suggesting an unsatisfactory implantation result. In sector 1 , the deviation reached $27^{\circ} 4^{\prime}$, which might have resulted from difficult anatomy. Summing up, the most significant divergence was observed in sector 1 .

\section{DISCUSSION}

The divergence between the insertion axes of the installed dental implants was significant $\left(27^{\circ} 4^{\prime}\right)$ in $87 \%$ of cases, falling outside of the acceptable values (Fig. 2). In this study, the axis was defined as a geometric center of an implant shaped as a regular cylinder.

The most significant divergence was observed in the projection of sector 1 , which is consistent with the findings of

Table 1. Demographic characteristics of the patients

\begin{tabular}{|c|c|c|c|c|c|}
\hline Sex & $18-25$ & $26-44$ & $45-65$ & Total & Number of patients, \% \\
\hline Males & 1 & 3 & 4 & 8 & 25 \\
\hline Females & 1 & 17 & 6 & 24 & 75 \\
\hline Total & 2 & 20 & 10 & 32 & 100 \\
\hline
\end{tabular}

Table 2. The number and size of the installed implants

\begin{tabular}{|c|c|c|c|c|c|}
\hline Diameter Number & 1 implant & 2 implants & 3 implants & Total & Number, \% \\
\hline 3.3 • $10.0(«$ MISS») & 4 & 2 & 0 & 6 & 16.2 \\
\hline 3.6 • 7.0 («Dentium») & 0 & 1 & 0 & 1 & 2.7 \\
\hline $3.75 \bullet 8.0(« \mathrm{MISS} »)$ & 6 & 2 & 0 & 8 & 21.6 \\
\hline 3.75 • $10.0(« M I S S »)$ & 2 & 2 & 0 & 4 & 10.8 \\
\hline 3.75 • $11.5(« M I S S »)$ & 5 & 1 & 0 & 6 & 16.2 \\
\hline 4.0 • $10.0(« \mathrm{MISS} »)$ & 0 & 0 & 1 & 1 & 2.7 \\
\hline $4.2 \cdot 8.0(« M I S S »)$ & 4 & 1 & 0 & 5 & 13.5 \\
\hline 4.2 • $10.0(« \mathrm{MISS} »)$ & 3 & 0 & 0 & 3 & 8.1 \\
\hline 4.2 • $11.5(« \mathrm{MISS} »)$ & 3 & 0 & 0 & 3 & 8.1 \\
\hline Total & 27 & 9 & 1 & 37 & 100.0 \\
\hline
\end{tabular}



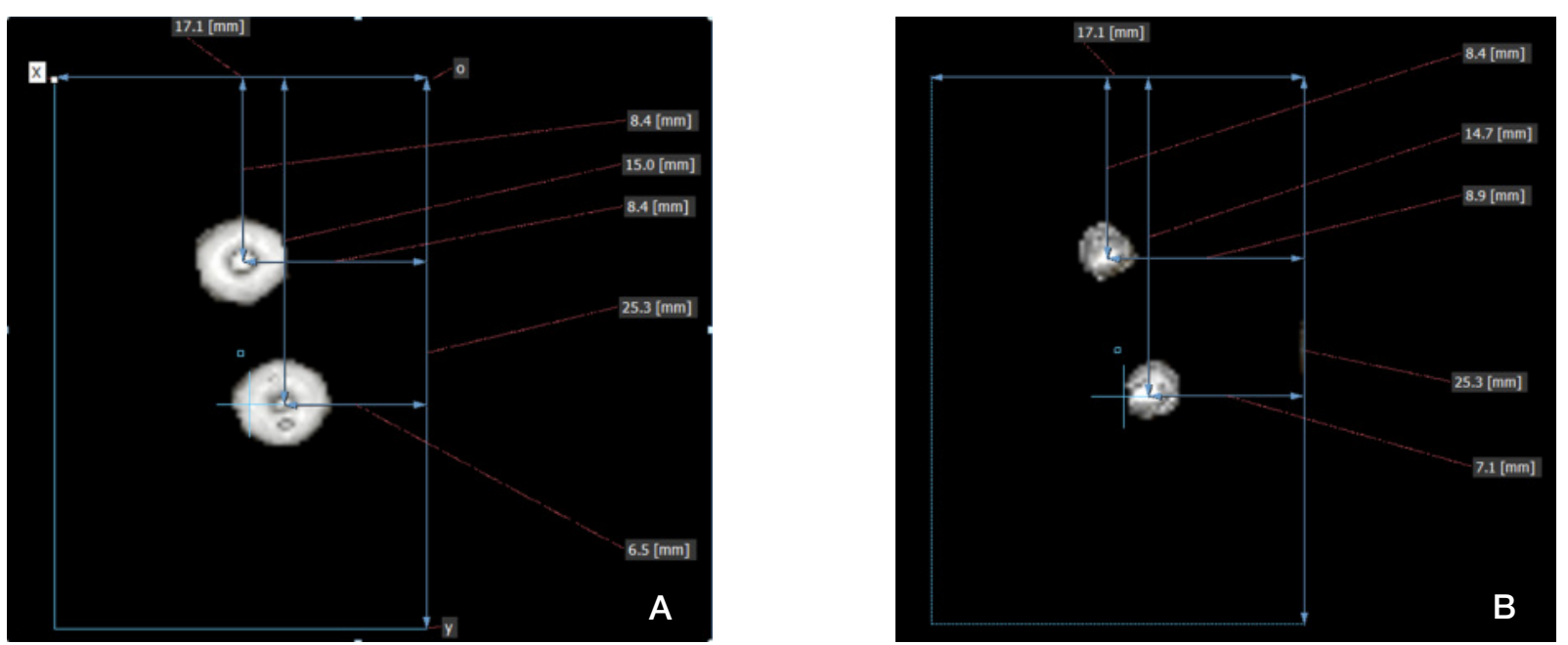

Fig. 1. A schematic representation of measurements performed by the original software developed by the authors. A. Neck coordinates of the implants. B. Apical coordinates of the implants

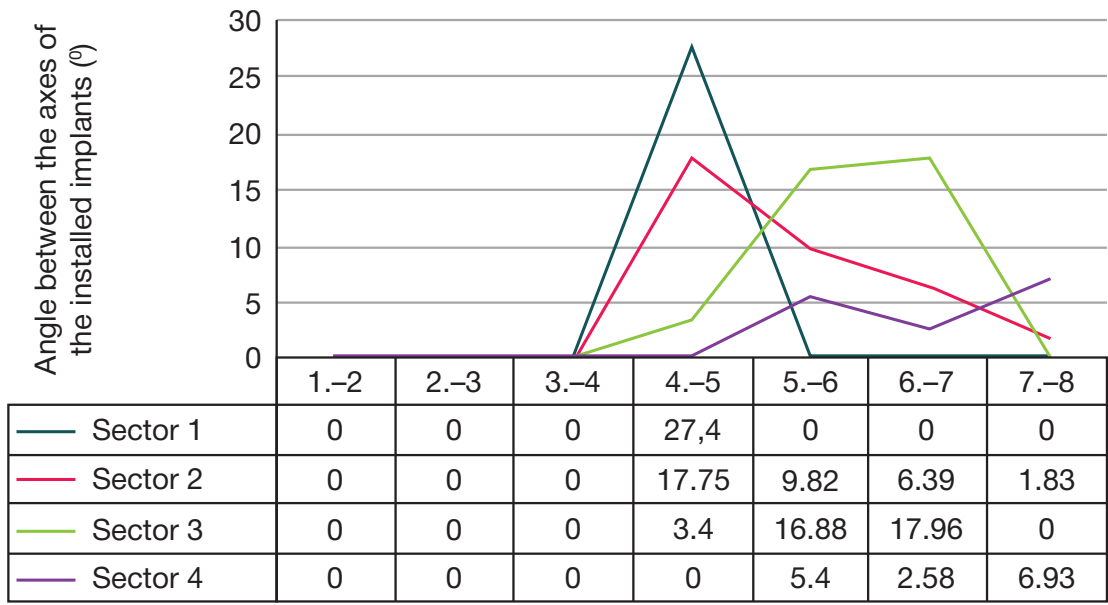

Fig. 2. Statistic values of divergence between the axes of the installed implants

other researchers $[6,12,15]$. The lowest statistically significant values were $\pm 0.5^{\circ}$. In the present study, the teeth were assigned to 4 sectors, according to the WHO classification: sector 1 , teeth 1.1 to 1.8 ; sector 2 , teeth 2.1 to 2.8 ; sector 3 , teeth 3.1 до 3.8; sector 4 , teeth 4.1 to 4.8 .

Understanding the effects of divergence between the installed implants on treatment outcomes and the importance of accurate implant placement is critical for the health of the entire dentofacial system.

\section{CONCLUSIONS}

In this work we studied the angles between the axes of the implants installed during a freehand surgical procedure. The freehand approach should be further improved by using mechanical devices and semi- or fully automatic systems for guiding dental implant placement. We recommend our mathematical model as a tool for measuring divergence between the axes of dental implants.

\section{References}

1. Klinicheskie rekomendacii (protokoly lechenija) pri diagnoze polnoe otsutstvie zubov (polnaja vtorichnaja adentija, poterja zubov vsledstvie neschastnogo sluchaja, udalenija ili lokalizovannogo parodontita). Utverzhdeny postanovleniem \# 15 soveta associacii obshhestvennyh ob"edinenij "Stomatologicheskaja associacija Rossii» ot 30 sentjabrja 2014 g. Dostupno po ssylke: www.estomatology.ru.

2. Potapov IV, Ivashhenko AV, Bajikov Al, Monakov DV, Monakov VA. Obosnovanie ispol'zovanija navigacionnoj sistemy $\vee$ dental'noj implantologii. Institut stomatologii. 2014; (4): 83-5.

3. Amhadova MA, Ignatov AYu. Dental'naja implantacija s primeneniem navigacionnogo implantologicheskogo shablona,

izgotovlennogo po tehnologii CAD/CAM. Stomatologija. 2011; (2): 49-52.

4. Olesova VN, Kashenko PV, Bronshtejn DA, Magamedhanov MYu, Havkin VA. Komp'juternoe planirovanie vnutrikostnoj dental'noj implantacii. Stomatologija. 2011; (2): 43-8.

5. Fedyaev IM, Hamadeeva AM, Nikolskij VYu, Ganzha IR. Vtorichnaja adentija pri dental'noj implantacii (jepidemiologicheskoe i sociologicheskoe issledovanie s pomoshh'ju metoda telefonnogo interv'ju). Stomatologija. 2004; 83 (6): 65-8.

6. Nesterov AP, Lepilin AV, Nesterov AV, Ulyanova SP. Vzaimosvjaz' polozhenija implantatov $v$ nizhnej cheljusti. Vestnik medicinskogo stomatologicheskogo instituta. 2016; 2 (37): 17-20. 
7. Fazullin FZ, Galieva Yel, Rjabyh LA. Snizhenie riska razvitija oslozhnenij dental'noj implantacii. V sbornike: Materialy HHIV Mezhdunarodnogo simpoziuma «Innovacionnye tehnologii $v$ stomatologii», posvjashhennogo 60-letiju stomatologicheskogo fakul'teta Omskogo gosudarstvennogo medicinskogo universiteta. Omsk: Izdatel'skij centr «KAN», 2017; 501-5.

8. Kan IV, Karerov MR, Samotesov PA, Shevchenko DP, Martynchuk DV. Vybor optimal'nogo diametra implantata pri neposredstvennoj stomatologicheskoj implantacii. Zhurnal anatomii i gistopatologii. 2018; 7 (1): 47-52.

9. Ushakov RV, Korkin W, Ushakov AR, Lyahovich AA. Kompleksnaja reabilitacija pacientov s polnym otsutstviem zubov. Rossijskij medicinskij zhurnal. 2011; (1): 34-7.

10. Ahmadova AM, Mohov AV, Muzaeva ZR. Ozdemirov MI, Shalabaeva KZ. Sposob uvelichenija keratinizirovannoj desny v oblasti implantatov $s$ ispol'zovaniem nebnogo soedinitel'notkannogo transplantata. Medicinskij alfavit. 2015; 3 (13): 28-30.

11. Saakjan $\mathrm{ShH}$, Kalamkarov AYe. Struktura izmenenij v al'veoljarnoj kosti pri ortopedicheskom lechenii pacientov s defektami zubnyh rjadov s ispol'zovaniem. Vestnik stomatologii i vnutrikostnyh implantatov. Rossijskij stomatologicheskij zhurnal. 2014; (2): 13-16.

12. Matveeva Al, Frolov VA, Gvetadze RSh, AG. Borisov Vlijanie implantata parametrov na naprjazhenno-deformirovannoe sostojanie kostnoj tkani zony implantacii. Stomatologija. 2010; (1): 54-5.

13. Chuyko AN i dr. Terminy: fiksacija i stabilizacija s pozicii biohimicheskogo analiza. Molodoy uchenyy. 2013; (9): 98-108.

14. Konchakovskiy AV, Konchakovskiy AA. Odnomomentnaja implantacija $\vee$ lunku udalennogo zuba i neposredstvennoe predvaritel'noe implantacionnoe protezirovanie akrilovymi konstrukcijami. Sovremennaja nauka: aktual'nye problemy teorii i praktiki. Serija: Estestvennye i tehnicheskie nauki. 2018; (7): 199-204.

15. Bayrikov IM, Ivashhenko AV, Layva OV, Kondrashin DV, Fedyaev IM, Nesterov AM. Klinicheskie vozmozhnosti navigacionnoj sistemy pri ustanovke dental'nyh implantatov. V sbornike: Aktual'nye voprosy stomatologii. Sbornik nauchnyh trudov, posvjashhennyj 50-letiju stomatologicheskogo obrazovanija v SamGMU. 2016; 124-134.

16. Sarmento HR, Dantas RVF, Pereira-Cenci T, Faot F. Elements of implant-supported rehabilitation planning in patients with bruxism. Journal of Craniofacial Surgery. 2012; 23 (6): 1905-9.

17. Eroshin VA, Dzhalalova MV, Arutjunov SD, Stepanov AG, Bagdasarjan GG. Podvizhnost' i kriterii gotovnosti dental'nyh implantatov k funkcional'nym nagruzkam. Sovremennye problemy nauki i obrazovanija. 2018; (2): 53.

\section{Литература}

1. Клинические рекомендации (протоколы лечения) при диагнозе полное отсутствие зубов (полная вторичная адентия, потеря зубов вследствие несчастного случая, удаления или локализованного пародонтита). Утверждены постановлением № 15 совета ассоциации общественных объединений «Стоматологическая ассоциация России" от 30 сентября 2014 г. Доступно по ссылке: www.e-stomatology.ru.

2. Потапов И. В., Иващенко А. В., Байриков А. И., Монаков Д. В., Монаков В. А. Обоснование использования навигационной системы в дентальной имплантологии. Институт стоматологии. 2014; (4): 83-5.

3. Амхадова М. А., Игнатов А. Ю. Дентальная имплантация с применением навигационного имплантологического шаблона, изготовленного по технологии CAD/CAM. Стоматология. 2011; (2): 49-52.

4. Олесова В. Н., Кашенко П. В., Бронштейн Д. А., Магамедханов М. Ю., Хавкин В. А. Компьютерное планирование внутрикостной дентальной имплантации. Стоматология. 2011; (2): 43-8.

5. Федяев И. М., Хамадеева А. М., Никольский В. Ю., Ганжа И. Р. Вторичная адентия при дентальной имплантации (эпидемиологическое и социологическое исследование с помощью метода телефонного интервью). Стоматология. 2004; 83 (6): 65-8.

6. Нестеров А. П., Лепилин А. В., Нестеров А. В., Ульянова С. П. Взаимосвязь положения имплантатов в нижней челюсти. Вестник медицинского стоматологического института. 2016; 2 (37): 17-20.

7. Фазуллин Ф. З., Галиева Э. И., Рябых Л. А. Снижение риска развития осложнений дентальной имплантации. В сборнике: Материалы XXIV Международного симпозиума «Инновационные технологии в стоматологии», посвященного 60-летию стоматологического факультета Омского государственного медицинского университета. Омск: Издательский центр «КАН», 2017; 501-5.

8. Кан И. В., Кареров М. Р., Самотесов П. А., Шевченко Д. П., Мартынчук Д. В. Выбор оптимального диаметра имплантата при непосредственной стоматологической имплантации. Журнал анатомии и гистопатологии. 2018; 7 (1): 47-52.

9. Ушаков Р. В., Коркин В. В., Ушаков А. Р., Ляхович А. А. Комплексная реабилитация пациентов с полным отсутствием зубов. Российский медицинский журнал. 2011; (1): 34-7.

10. Ахмадова А. М., Мохов А. В., Музаева З. Р. Оздемиров М. И., Шалабаева К. З. Способ увеличения кератинизированной десны в области имплантатов с использованием небного соединительнотканного трансплантата. Медицинский алфавит. 2015; 3 (13): 28-30.

11. Саакян Ш. Х., Каламкаров А. Э. Структура изменений в альвеолярной кости при ортопедическом лечении пациентов с дефектами зубных рядов с использованием. Вестник стоматологии и внутрикостных имплантатов. Российский стоматологический журнал. 2014; (2): 13-16.

12. Матвеева А. И., Фролов В. А., Гветадзе Р. Ш., Борисов А. Г. Влияние имплантата параметров на напряженнодеформированное состояние костной ткани зоны имплантации. Стоматология. 2010; (1): 54-5.

13. Чуйко А. Н. и др. Термины: фиксация и стабилизация с позиции биохимического анализа. Молодой ученый. 2013; (9): 98-108.

14. Кончаковский А. В., Кончаковский А. А. Одномоментная имплантация в лунку удаленного зуба и непосредственное предварительное имплантационное протезирование акриловыми конструкциями. Современная наука: актуальные проблемы теории и практики. Серия: Естественные и технические науки. 2018; (7): 199-204.

15. Байриков И. М., Иващенко А. В., Лайва О. В., Кондрашин Д. В., Федяев И. М., Нестеров А. М. Клинические возможности навигационной системы при установке дентальных имплантатов. В сборнике: Актуальные вопросы стоматологии. Сборник научных трудов, посвященный 50-летию стоматологического образования в СамГМУ. 2016; 124-134.

16. Sarmento HR, Dantas RVF, Pereira-Cenci T, Faot F. Elements of implant-supported rehabilitation planning in patients with bruxism. Journal of Craniofacial Surgery. 2012; 23 (6): 1905-9.

17. Ерошин В. А., Джалалова М. В., Арутюнов С. Д., Степанов А. Г., Багдасарян Г. Г. Подвижность и критерии готовности дентальных имплантатов к функциональным нагрузкам. Современные проблемы науки и образования. 2018; (2): 53. 